\title{
Gender Wage Disparities in Medicine: Time to Close the Gap
}

\author{
A. Sofia Warner, MD, MBA ${ }^{7}$ and Lisa Soleymani Lehmann, MD, $P h D^{2,3,4}$
}

'Department of Medicine, Massachusetts General Hospital, Boston, MA, USA; ${ }^{2}$ VA New England Healthcare System, Bedford, MA, USA; ${ }^{3}$ Department of Medicine, Harvard Medical School, Boston, MA, USA; ${ }^{4}$ Department of Health Policy and Management, Harvard T. H. Chan School of Public Health, Boston, MA, USA.

Women physicians are paid less than their male peers across medical specialties and geographies. While the medical literature to date has focused on documenting the existence of a wage gap, less attention has been paid to fixing this gap. We focus on interventions around auditing, salary transparency, family leave, and childcare that can be implemented to advance gender wage parity.

KEY WORDS: gender; physician compensation; wage gap; disparities; bias.

J Gen Intern Med 34(7):1334-6

DOI: $10.1007 / \mathrm{s} 11606-019-04940-9$

(c) Society ofGeneral Internal Medicine (This is a U.S. government work and not under copyright protection in the U.S.; foreign copyright protection may apply) 2019

$\mathrm{T}$ he gender wage gap in medicine demands attention and remediation. Women currently make up $47.5 \%$ of US medical school graduates, yet studies show a persistent wage gap between men and women physicians across nearly all specialties and geographies after adjusting for hours worked, years in the profession, and medical specialty. ${ }^{1-7}$ One study found that at 24 public US medical schools, women's salaries were on average $8.0 \%$ or $\$ 19,879$ less than men's, a difference that was present at all faculty ranks. ${ }^{8}$ While there may be a perception that women physicians earn less because they work fewer hours or see fewer patients, when adjusted for these factors, women MDs still earn less than their male peers. ${ }^{3,}$ 4, 9 The gap in women physicians' pay is likely due to several factors, from basing salaries on historically unequal pay, to institutional factors including overt and implicit bias, to cultural factors such as perceptions of women's career aspirations and goals, especially once they have children. The medical literature to date has largely focused on documenting the existence of a wage gap, and less attention has been given to fixing this gap. ${ }^{10,11}$ We focus on specific interventions organizations can implement to reduce the gender wage gap and compensate women physicians fairly for their work.

Received May 13, 2018

Revised December 17, 2018

Accepted February 22, 2019

Published online April 8, 2019
In their Guide to Gender Pay Equity, the Australian government outlines three types of gender pay gap analyses: likefor-like gap analyses which compare salaries of men and women doing equivalent work, by-level gap analyses which compare salaries of men and women with similar job titles, and organizational-level gap analyses which compare the average salaries of all men and women in an organization. ${ }^{12}$ In this paper, we will focus primarily on like-for-like gender wage gaps and organizational-level gaps.

How can we achieve wage equity? First, organizations can commit to auditing, reporting, and correcting gender disparities in like-for-like pay. In response to the California Fair Pay Act of 2015, which required companies to justify differences in salaries between men and women doing the same job, UCSF found that some women were being paid less than their male peers. ${ }^{13}$ As a result of this analysis, 131 faculty in the UCSF School of Medicine received salary adjustments totaling $\$ 1.577$ million. This analysis took into account many of the complexities of physician pay, evaluating base salary, negotiated salary, clinical incentives, and leadership positions, and then used a matchedpair analysis to look for outlier salaries. ${ }^{14}$ Johns Hopkins published a similar analysis in 2014 which showed that women faculty members were paid $3.4 \%$ less in terms of FTE salary and $8.6 \%$ less in total salary. ${ }^{15}$ Institutions and physicians groups can commit to undertaking these analyses to ensure their physicians are paid equitably. ${ }^{16}$

Another approach to addressing the like-for-like wage gap is salary transparency. This is the approach that several physicians' organizations, including hospitalists at John Muir in California and the social media company Buffer, have taken. ${ }^{17,18}$ One of the ways that women under-earn compared to men is that they ask for less money when negotiating salaries. ${ }^{19}$ If salaries are available for any employee to look up, women will have more salary data to use as reference points when negotiating. While pay transparency is not mandatory in the USA, in Sweden, where the gender pay gap is narrower than that in the USA, salaries are available through a public income tax database, enabling anyone to look up their coworker's salary. ${ }^{20}$ However, negotiation alone is unlikely to erase the like-for-like wage gap. Studies have shown that women have a reason to be reluctant to negotiate: they often face backlash for doing so. ${ }^{21}$ Additionally, research has shown that even when women negotiate as often as men, they are less 
likely to receive a raise. ${ }^{22}$ Importantly, Buffer realized they could not rely on salary transparency to fix their organizational-level pay gap of women being paid less than men. They have since reassessed their pay structure as an additional method of addressing a like-for-like pay gap and focused on recruiting more women into senior positions to address their organizational pay gap. ${ }^{23,24}$

In addition to auditing and salary transparency, companies can avoid perpetuating an existing gender wage gap. Organizations that base employees' pay on the individual's historical salary may be perpetuating an existing wage gap, intentionally or not. Several states and cities have passed laws explicitly prohibiting employers from asking about salary history, including Massachusetts, Philadelphia, and New York. ${ }^{25}$ Organizations can commit to not asking about salary history, regardless of their local laws, when hiring physicians and tying pay to the particular role the individual is being hired for rather than their previous salary.

Employers can also focus on an important time in women's careers when they are particularly likely to face both like-forlike and organizational wage gaps - when they have children. A recent National Bureau of Economics working paper shows that while women have made significant gains towards wage equity in the past several decades, "most of the remaining gender inequality in earnings is due to children." ${ }^{26}$ Having children adversely affects the wages of women in high-earning occupations, like medicine, while men with children often see an increase in their wages, effects that have been termed the "motherhood penalty" and "fatherhood bonus." 7, 27 Studies of physicians have shown that women with children work on average 10 fewer hours per week compared with women physicians without children and among male and female physician scientists, women physician parents spend 8.5 more hours per week on domestic tasks. ${ }^{28,}{ }^{29}$ As Dr. Jolly and her colleagues conclude, for women "time spent on domestic labor competes with working time." $" 29$ Additionally, economist Claudia Goldin has shown that "even when mothers cut back at work, they are not paid proportionately less ... they are still paid less than men for the hours they work." ${ }^{30}$ To address the like-for-like and organizational wage gap women physicians face when having children, employers can audit their payrolls to make sure that women who choose to work fewer hours are being paid equitably. Additionally, women who become mothers are often discriminated against, recommended for lower starting salaries, seen as less competent, and passed over for promotions based on the assumption that they do not want a more senior role if they have young children at home. ${ }^{31}$ This type of discrimination contributes to the organizational wage gap and hinders women physicians' career advancement. Employers can push back against this type of discrimination by considering a wide pool of candidates for leadership positions and promotions and by making sure that women who are mothers are not excluded based on assumptions about their career aspirations.
The provision of on-site or subsidized childcare can also address the organizational wage gap by mitigating the trend of women physicians decreasing their hours at work once they have children. These types of initiatives, which make it easier for women to stay at work rather than cutting back on work hours to care for their children, have had impressive results at companies like Patagonia, Home Depot, and Clif Bar. ${ }^{32}$ Patagonia CEO Rose Marcario has argued that there is a strong business case for providing on-site childcare: Patagonia recoups about $91 \%$ of the roughly $\$ 1$ million in costs through tax credits, improved employee engagement, and low turnover among staff who use the daycare program. ${ }^{33}$ At Patagonia's headquarters, $100 \%$ of women who have had children while working at the company have returned to work, and roughly $50 \%$ of managers and senior leadership are women. ${ }^{31}$ Given that the cost of replacing a physician, including lost revenue and recruitment costs, is estimated between $\$ 250,000$ and $\$ 1$ million, offering childcare benefits that are accessible and affordable makes financial sense for employers. ${ }^{34}$

It is time to move from documenting the existence of a gender wage gap to closing the gap between men and women physicians.

Corresponding Author: Lisa Soleymani Lehmann, $M D, P h D$; , Boston, MA, USA

\section{Compliance with Ethical Standards:}

Conflict of Interest: The authors declare that they do not have a conflict of interest.

Disclaimer: The opinions expressed are those of the authors and do not reflect the views of the National Center for Ethics in Health Care, the Department of Veterans Affairs, Massachusetts General Hospital, or Harvard University.

\section{REFERENCES}

1. Doximity Second Annual Physician Compensation Report. Doximity, 2018. Available at: https://www.doximity.com/careers/compensation report?_csrf_attempted=yes\&_remember_me_attempted=yes. Accessed 23 January 2019.

2. Lo Sasso AT, Richards MR, Chou CF, Gerber SE. The \$16,819 Pay Gap For Newly Trained Physicians: The Unexplained Trend Of Men Earning More Than Women. Health Aff (Millwood) 2011;30(2):193-201.

3. Jagsi R, Biga C, Poppas A, et al. Work Activities and Compensation of Male and Female Cardiologists. J Am Coll Cardiol 2016;67(5):529-41.

4. Jagsi R, Griffith KA, Stewart A, Sambuco D, Decastro R, Ubel PA. Gender Differences in the Salaries of Physician Researchers. JAMA. 2012;307(22):2410-7.

5. Weaver AC, Wetterneck TB, Whelan CT, Hinami K. A Matter of Priorities? Exploring the Persistent Gender Pay Gap in Hospital Medicine. J Hosp Med 2015; 10(8):486-90.

6. Apaydin EA, Chen PGC, Friedberg MW. Differences in Physician Income by Gender in a Multiregion Survey. J Gen Intern Med 2018;33(9):15741581 .

7. Read S, Butkus R, Weissman A, Moyer DV. Compensation Disparities by Gender in Internal Medicine. Ann Intern Med 2018;169(9): 658-661.

8. Jena AB, Olenski AR, Blumenthal DM. Sex Differences in Physician Salary in US Public Medical Schools. JAMA Intern Med 2016;176(9):1294-304. 
9. Wallace AE, Weeks WB. Differences in Income Between Male and Female Primary Care Physicians. J Am Med Womens Assoc (1972) 2002;57(4): 180-4.

10. Sanfey H, Crandall M, Shaughnessy E, et al. Strategies for Identifying and Closing the Gender Salary Gap in Surgery. J Am Coll Surg 2017;225(2):333-338.

11. Morgan AU, Chaiyachati KH, Weissman GE, Liao JM. Eliminating Gender-Based Bias in Academic Medicine: More Than Naming the "Elephant in the Room". J Gen Intern Med 2018;33(6):966-968.

12. Workplace Gender Equality Agency, Australian Government. Guide to gender pay equity. Available at: https://www.wgea.gov.au/sites/default/ files/documents/guide-to-gender-pay-equity.pdf. Accessed 23 January 2019.

13. Fost D. UCSF Faculty Salary Equity Review Finds Few Gender-Based Inequities. UCSF News Center. February 12, 2016. Available at: https:// www.ucsf.edu/news/2016/02/401571/ucsf-faculty-salary-equity-review-finds-few-gender-based-inequities?utm_source=feed\&utm medium=rss\&utm_campaign=Feed $\% 3 A+U C S F+N e w s$. Accessed 23 January 2019.

14. Faculty Salary Equity Review (FSER) Committee. Report from the UCSF Faculty Salary Equity Review Committee (FSER). July 2018. Available at: https://academicaffairs.ucsf.edu/academic-personnel/other/fser/ FSER\%202018\%20Report.pdf. Accessed 23 January 2019.

15. 2014 Report on Johns Hopkins University School of Medicine Faculty Salary Analysis, Fiscal Year 2013. Available at: https://www. hopkinsmedicine.org/som/_documents/2014_faculty_salary_analysis. pdf. Accessed 23 January 2019

16. Chamberlain A. How to Analyze Your Gender Pay Gap: An Employer's Guide. Glassdoor. April 2017. Available at: https://www.glassdoor.com/ research / app/uploads / sites / 2 / 2017 /04/GD_Report_ AnalyzingGenderPayGap_Rebrand.pdf. Accessed 23 January 2019.

17. Gesensway D. Gender Gap in Hospital Medicine: Do Women Have the Same Opportunities? Today's Hospitalist. March, 2016. Available at: https://www.todayshospitalist.com/Gender-gap-in-hospital-medicineDo-women-have-the-same-opportunities/. Accessed 23 January 2019.

18. Gascoigne J. Introducing Open Salaries at Buffer: Our Transparent Formula and All Individual Salaries. Buffer. December 19, 2013, updated August 27, 2018. Available at: https://open.buffer.com/introducingopen-salaries-at-buffer-including-our-transparent-formula-and-all-individual-salaries/. Accessed 23 January 2019.

19. Babcock L, Laschever S, Gelfand M, Small D. Nice Girls Don't Ask. Hary Bus Rev 2003. Available at: https://hbr.org/2003/10/nice-girls-dontask . Accessed 23 January 2019.

20. Marçal K. Sweden shows that pay transparency works. Financial Times. July 27, 2017. Available at: https://www.ft.com/content/2a9274be72aa-11e7-93ff-99f383b09ff9 . Accessed 23 January 2019.

21. Amanatullah ET, Morris Mw. Negotiating Gender Roles: Gender Differences in Assertive Negotiating Are Mediated by Women's Fear of Backlash and Attenuated When Negotiating on Behalf of Others. J Pers Soc Psychol 2010;98(2):256-67.
22. Artz B, Goodall A, Oswald AJ. Do Women Ask? Ind Relat (Berkeley) 2018;57(4):611-636.

23. Griffis H. On the Journey to Equal Pay: Here's Exactly What Men and Women Earn at Buffer. Buffer. April 4, 2017, updated April 10, 2018. Available at: https://open.buffer.com/equal-pay/. Accessed 23 January 2019.

24. Lam B. When Everyone Knows How Much Everyone Else Is Paid. The Atlantic. March 28, 2016. Available at: https://www.theatlantic.com/ business/archive/2016/03/pay-transparency-gender-gap/475683/. Accessed 23 January 2019.

25. Cain A, Pelisson A, Gal S. 9 places in the US where job candidates may never have to answer the dreaded salary question again. Business Insider. April 10, 2018. Available at: https://www.businessinsider.com/ places-where-salary-question-banned-us-2017-10 . Accessed 23 January 2019.

26. Kleven H, Landais C, Sogaard J. Children and Gender Inequality: Evidence from Denmark. NBER Working Paper 24,219. Available at: https://www.nber.org/papers/w24219. Accessed 23 January 2019.

27. Sasser AC. Gender Differences in Physician Pay: Tradeoffs between Career and Family. J Hum Resour 2005;40(2):477-504.

28. Ly DP, Seabury SA, Jena AB. Hours Worked Among US Dual Physician Couples with Children, 2000 to 2015. JAMA Intern Med 2017;177(10):1524-1525.

29. Jolly S, Griffith KA, Decastro R, Stewart A, Ubel P, Jagsi R. Gender Differences in Time Spent on Parenting and Domestic Responsibilities by High-Achieving Young Physician-Researchers. Ann Intern Med 2014;160(5):344-53.

30. Cain Miller C. The Gender Pay Gap Is Largely Because of Motherhood. The New York Times. May 13, 2017. Available at: https://www.nytimes. com/2017/05/13/upshot/the-gender-pay-gap-is-largely-because-ofmotherhood.html. Accessed 23 January 2019.

31. Correll SJ, Benard S, Paik I. Getting a Job: Is There a Motherhood Penalty? Am J Sociol 2007;112(5): 1297-1338.

32. Feintzing $\mathbf{R}$. The Case for Day Care at the Office. The Wall Street Journal. September 26, 2016. Available at: https://www.wsj.com/articles/the-case-for-day-care-at-the-office-1474882201. Accessed 23 January 2019.

33. Marcario R. Patagonia's CEO Explains How to Make On-Site Child Care Pay for Itself. Fast Company. August 15, 2016. Available at: https://www. fastcompany.com/3062792/patagonias-ceo-explains-how-to-makeonsite-child-care-pay-for-itself Accessed 23 January 2019.

34. Berg S. At Stanford, Physician Burnout Costs at Least \$7.75 Million a Year. AMA Wire. November 17, 2017. Available at: https://wire.ama-assn. org/life-career/stanford-physician-burnout-costs-least-775-million-year. Accessed 23 January 2019.

Publisher's Note: Springer Nature remains neutral with regard to jurisdictional claims in published maps and institutional affiliations. 